\title{
Black Series
}

\author{
Angela Brown \\ College of Southern Nevada, USA \\ E-mail: brownlas6@aol.com
}

Received: 15-06- 2013

Accepted: 22-07- 2013

Published: 31-07- 2013

doi:10.7575/aiac.ijclts.v.1n.2 p.44

URL: http://dx.doi.org/10.7575/aiac.ijclts.v.1n.2p.44

\section{Clock Work}

What matters most,

Is of what is the least.

We cross signals that overlap,

And chase after signs

Which have loss all reason.

In unison with hope, we lose confrontation.

Within seconds as we withdraw

From what matters at all.

Time does not meet expectations,

When our emotions only lie dead,

In a galaxy full of stars.

\section{Paranoia}

In the dark, misty woods

Lies a shallow creek, where hornets

Rest and crickets prey.

A firefly creates life, flickering in the night,

Shining its tail like match sticks

Frightened of rejection.

Deathly gestures call, as they shine,

Like stars dancing inside of

An empty jar.

\section{Social Path}

A portrayer of dreams.

Her weariness was over processed -

Her demeanor was sensitive.

Her conflict with an inner voice

Made her more insecure

And out of touch with her reality.

She absorbed darkness

For her dreams shifted

Into a cold bitterness that killed her. 
Trayvon Martin Voice

Emotions for hunger has not

Been abandoned. Cries for

love nurtures a desire to be free.

Abandonment is a captive of hatred.

Dreams are an illusion.

Dreams makes a desire to prey

A conduit of self-doubt.

Intuition relies on the power to

to live without fear. For wisdom

validates reason

To be recognized by imagery.

\section{Trayvon Martin}

Repair my broken heart

Bind it with glue

Train me to feel

Show me your purpose

Teach me to love

Talk to me

Be fair to me, I ask

Become a testimony of faith

Determined and unbiased

Become an advocate of God's fate

To be remembered.

\section{Manic Depressive}

Love will not surrender to dust

It is death that weakens the soul.

Death that has taken its toll,

While seeking freedom. Women who die

Have lost the war, for her soul

Purpose thrives to live.

Women are afraid to die.

To embrace fate,

She masters death.

Women lose in sorrow,

Have become a captive of

self-doubt.

\section{Kleptomaniac}

Imagine the universe

Of deprivation.

An horizon of burning desire

Accompanied by the anxiety

To succeed. 
Imagine suppression

of power.

Trapped in a parody

Of bias pleasures.

A path that lies within the shadows,

Of contempt.

\section{Neurotic Lesbian}

Where I have fears

That ceases to be...

To thirst is an anxiety.

To crave is a silent fear.

For hunger is a desire

That fixates an unsatisfied quench

Of sanctuary lust.

There is a dark place

Disturbed from heaven.

The flames imbalanced by

A contingency which defies God.

To feel the insanity

Of an obsessed addiction

I chide in ripe chains.

The passion I live

Belongs to us.

\section{Phobia}

To dread the terror

Of fear is

To engage in

oriented tasks.

The anxiety of leading an

Independent fight

Is an irrational horror

To imagine.

Suspicion is

Fear itself

Which questions the

Confidence of distress. 
A delusion is a passion

To escape reality

Beyond guided trust.

\section{Pigeon}

A messenger, a currier, an emissary clan

Who have escaped from deprivation

And crossed over distant foreign land.

Who have faced much malice,

Worth a grain of sand.

And you undermined all reason,

To be called carriers of disease.

You spread your wings swiftly in the wind,

As you glide onto ground,

to humbly beg for a small crumb.

You wear the mask,

Hidden in disguise.

You are a martyr by fate,

And at peace by night.

\section{Nelson Mandela, By Angela K Brown}

There is a discipline to adhere

Amongst men.

There is a right to conviction

Amongst the oppressed.

Mandela fought against deprivation

To dictate a discipline of equality

Towards a free society,

For a more organized learning climate,

For the idea of unified democracy, with

A promise to affirm with earnest solemnity.

A long walk to freedom...

\section{Ornate with Smoke}

My life is in pieces. I am confused. My life cannot go on.

This is something hard to admit to. It is hard to accept. January 23, 1998 was the time of my conception. It happens to people like me all the time. I am the easy go figure type that submits to a married man. I left the old job so I would not interfere with his marriage. Several months past. It was now August. I was scheduled for an ultrasound. I could not admit my guilt of adultery. What would people think of me? Having a baby out of wedlock to a married man would ruin my family's reputation. I would be belittled with mockery and hatred with the thought of deceiving God. I felt this time was different. I never loved a man more. I was caught in a tragic accident of having relationships with married men. I know it is wrong of me to do so. It is not entirely all my fault, the men do not admit to it until after they are caught. I lost my brother on February 23, 1998. I feel I cannot go on. The daddy lost his first child to a miscarriage. Where do I fit in? It is me, he and she. What am I supposed to do? I felt I must walk away and pretend it would just go away. Poof, it's gone in one blow. How does one admit you cheated? I did not know what to do. I know how hard it is to be a single mom, especially without father's support. Why did God let this happen? I decided to have the baby aborted the time of the ultra sound. This is a secret that I must take up with my God. I am not a murderer. I was actually hoping he would leave his wife for me. I thought I loved this man more than anyone else. He is a fatal attraction from another lost relationship. There is nothing I can do with a married man. I do not think it is possible to replace the baby daddy. I cannot replace our baby. There is nothing any man can do with a woman who cannot conceive a child. I lost my chance. I must find piece in my heart to love others. After him, there are no commitments, while I gave my soul to God. If I held 
the secret I kept from him. There is not a day that goes by that I wonder what if, I saw my child grow up, knowing what are her interest are, knowing what she looks like, seeing her achieve and most of all knowing is she happy? If I had the chance to start all over again, I would breathe life back into my child's heart and let her live. I was alone. I was confused. I was scared of what people would say or think; but, it is something that I will never forget. I hope he forgives me. There is something I feel I must say...

\section{Lesbian Lover Letter}

Dear My Lover,

...I am waiting for your return. Often I am reminded of you. All the years I have gone on laughing at our mistakes. It is mature when one can laugh at their own mistakes. You made me realize how valuable you are in my Life. I never doubted family. You made me realize the importance of having someone in my life. I imagine the unexpected. You did not leave. Your presence is forever in my memory. I admit it is my fault to question the validity of our love. As I grow older, I respect you more. You never said I was right to without our feelings. Learning to cry is meaningful. I do not hold it against you. It is the idea that makes our love true. Instead you touch my life with kind words and a gentle heart. I lie still nourishing my mind with spirituality of your presence in my life. I am grateful for your love. The idea of "love" is in question. I ask God for your return. I lie busy in starvation of the desire of having family back in my life once more...

...to the young women of the universe searching to find her soul, her true identity and her heart. She has been abandoned from love.. It happened expectantly when she lost her true

love for her abandoned child within when she lost touched of reality of being neglected by her father...

...to the young women searching to find her soul... She has been abandoned from love.. It happens when your spirituality escapes from being different, by wanting to voice your

opinion in a closed climate of losing child to a miscarriage of irreconcilable differences victimized by spousal abuse that repetition... his heart is with another and not you... of reality

of being neglected...

...to the young women searching for her true identity... She has been abandoned from love.. To manipulate play by manhandling unspoken challenges to ratify the female status with vague restrictions...to trust the voices in her head that deny everything she tried to accomplish is refutable...

...relationship with her inner self to tell her to quit or die... of reality of being neglected ...to the young women of the universe searching to find her heart... She has been abandoned from love.. To suicide because she felt she has no reason to try irresponsible reasoning because her children left her for maturation to move on, her baby's daddy died when he went to prison and her friends moved on...her heart still cares to listen to her vocation, the only reason she stays in good health... of reality of being neglected...in keeping it real the father is God...God who left her

with no faith after her lost... She has been abandoned from love...the reason for her loss is she neglected to believe others cared, God cares...the reason she lost reality is how she neglected to pray asking for God to carry her for she was not alone...she neglected to listen to God's voice encouraging her fate...searching for her soul, searching for her identity... searching for her heart...the reality of being neglected left when she lost touch with her God.. a reality of being neglected...

...An image of a storm perturbs warm waters

A shadows emerges an overcast of hope

Hovering over in silence, embracing for peace...

...Time's client is an admissive stare

Ghostly hands deplete death entrapment, of being raped, beaten and verbally abused

has given a sign to escape insanity,

Trying to vacate this cage of unsought welcome... 
... If tears could speak, it speaks of fear

And the new born will never speak in silence ...

I walk like I am disabled, I carry the load of intolerance, I may be used, I may be abused, I have been lied on, I have been beaten, I may be lonely, I may be seduced, and in my prayers and dreams, Shattered the truth...I am weak, but, I don't feel old at all. Amen.

Since childhood is the golden age of human being's life, Le Clezio has tried to introduce children as the main heroes in most of his works. In Le Clezio's works, child is the symbol of freedom, purity and simplicity. Such an attitude towards the child and children's world makes the writer to depict a close connection that exists between the child and the world realities such as society, nature and happiness. He writes about a society full of dirt, a nature that its elements speak to the child and a kind of happiness that the child himself creates in the world. 